Social Sciences, Humanities and Education Journal (SHE Journal)

Volume 2 (2) 132 - 146, May 2021 | ISSN: 2720-9946 (Online) | ISSN: 2723-3626 (Print)

The article is published with Open Access at: http://e-journal.unipma.ac.id/index.php/SHE

\title{
ROLE OF ACTIVE KNOWLEDGE SHARING LEARNING METHOD IN IMPROVING ENGLISH LEARNING ACHIEVEMENT FOR STUDENT OF XII-IPA-1 CLASS AT SMA NEGERI 2 MADIUN CITY IN ACADEMIC YEAR 2019/2020
}

Warsito $\bowtie$; SMAN 2 Madiun, Kota Madiun

\begin{abstract}
This study aims to: (a) record the improvement of student achievement by applying the Active Knowledge Sharing Learning method; and (b) uncover the effect of student learning motivation by applying the Active Knowledge Sharing Learning method. This research used class action research in three cycles. Each consists of design, activities and observations, reflection, and revision. The subjects of this research are students of the XII -IPA-1 Class at SMA Negeri 2 Madiun City in Academic Year 2019/2020. The data were obtained by using formative test and observation. Results reveal that the student learning achievement increased from cycle I to cycle III (69.66\%), cycle II (74.53\%), and cycle III (83.09\%). This study concluds that app lying the Active Knowledge Sharing Learning method has a positive effect on the achievement and learning motivation for students.
\end{abstract}

Keywords: Active Knowledge Sharing Learning Method, Physical Learning Achievement .

$\bowtie$ warsito_jalal@yahoo.com

Citation: Warsito, W. (2021). Role of active knowledge sharing learning method in improving english learning achievement for student of XII-IPA-1 class at SMA Negeri 2 Madiun City in academic year 2019/2020. Social Sciences, Humanities and Education Journal (SHE Journal), 2(2), 136 - 146. DOI: 10.25273/she.v2i2.9231

\section{(cc) $B Y-N C-S A$}




\section{PENDAHULUAN}

Pada hakekatnya kegiatan belajar mengajar adalah suatu proses interaksi atau hubungan timbal balik antara guru dan siswa dalam satuan pembelajaran. Guru sebagai salah satu komponen dalam proses belajar menganjar merupakan pemegang peran yang sangat penting. Guru bukan hanya sekedar penyampai materi saja, tetapi lebih dari itu guru dapat dikatakan sebagai sentral pembelajaran.

Sebagai pengatur sekaligus pelaku dalam proses belajar mengajar, gurulah yang mengarahkan bagaimana proses belajar mengajar itu dilaksanakan. Karena itu guru harus dapat membuat suatu pengajaran menjadi lebeh efektif juga menarik sehingga bahan pelajaran yang disampaikan akan membuat siswa merasa senang dan merasa perlu untuk mempelajari bahan pelajaran tersebut.

Guru mengemban tugas yang berat untuk tercapainya tujuan pendidikan nasional yaitu meningkatkan kualitas manusia Indonesia, manusia seutuhnya yang beriman dan bertakwa terhadap Tuhan Yang Maha Esa, berbudi pekerti luhur, berkepribadian, berdisiplin, bekerja keras, tangguh, bertanggung jawab, mandiri, cerdas dan terampil serta sehat jasmani dan rohani, juga harus mampu menumbuhkan dan memperdalam rasa cinta terhadap tanah air, mempertebal semangat kebangsaan dan rasa kesetiakawanan sosial. Sejalan dengan itu pendidikan nasional akan mampu mewujudkan manusia-manusia pembangunan dan membangun dirinya sendiri serta bertanggung jawab atas pembangunan bangsa (Depdikbud, 1999).

Berhasilnya tujuan pembelajaran ditentukan oleh banyak faktor diantaranya adalah faktor guru dalam melaksanakan proses belajar mengajar, karena guru secara langsung dapat mempengaruhi, membina dan meningkatkan kecerdasan serta keterampilan siswa. Untuk mengatasi permasalahan di atas dan guna mencapai tujuan pendidikan secara maksimal, peran guru sangat penting dan diharapkan guru memiliki cara/model mengajar yang baik dan mampu memilih model pembelajaran yang tepat dan sesuai dengan konsep-konsep mata pelajaran yang akan disampaikan.

Tujuan pendidikan nasional seperti yang terdapat dalam Undangundang Nomor 20 tahuan 2003 yaitu mencerdaskan kehidupan bangsa dan mengembangkan manusia Indonesia yang beriman dan bertakwa terhadap Tuhan Yang Maha Esa dan berbudi luhur, memiliki pengetahuan dan keterampilan, sehat jasmani dan rohani kepribadian yang mantap dan mandiri serta bertanggung jawab kemasyarakatan bangsa (Departemen Pendidikan dan Kebudayaan, 1998: 3). Tujuan pendidikan nasional ini sangat luas dan bersifat umum sehingga perlu dijabarkan dalam Tujuan Institusional yang disesuaikan dengan jenis dan tingkatan sekolah yang kemudian dijabarkan lagi menjadi tujuan kurikuler yang merupakan tujuan kurikulum sekolah yang diperinci menurut bidang studi/mata pelajaran atau kelompok mata pelajaran (Purwanto, 1988 :2). Tujuan instruksional dijabarkan menjadi Tujuan Pembelajaran Umum dan kemudian dijabarkan lagi menjadi Tujuan Pembelajaran Khusus (TPK).

Dalam mencapai Tujuan

Pembelajaran Khusus pada mata pelajaran Bahasa Inggris di Sekolah Menengah Atas, khususnya di Siswa Kelas XII-IPA-1 Semester Ganjil di SMA Negeri 2 Madiun, Kota Madiun pada Tahun Pelajaran 2019/2020. masih banyak mengalami kesulitan. Hal ini terlihat dari masih rendahnya nilai mata pelajaran Bahasa Inggris dibandingkan dengan nilai beberapa mata pelajaran lainnya, mata pelajaran Bahasa Inggris peringkat nilainya menempati urutan paling bawah dari mata pelajaran yang lainnya, bertitik tolak dari hal tersebut di atas perlu pemikiran-pemikiran dan tindakan- 
tindakan yang harus dilalukan agar siswa dalam mempelajari konsep-konsep Bahasa Inggris tidak mengalami kesulitan, sehingga tujuan pembelajaran khusus yang dibuat oleh guru mata pelajaran Bahasa Inggris dapat tercapai dengan baik dan hasilnya dapat memuaskan semua pihak. Oleh sebab itu penggunaan metode pembelajaran dirasa sangat penting untuk membantu siswa dalam memahami konsep-konsep Bahasa Inggris.

Sesuai dengan permasalahan di atas, penelitian ini bertujuan untuk: (1) mengetahui peningkatan prestasi belajar siswa setelah diterapkannya metode Active Knowledge Sharing Learning, dan (2) mengetahui pengaruh motivasi belajar siswa setelah diterapkan metode Active Knowledge Sharing Learning.

Pembelajaran adalah proses, cara, menjadikan orang atau makhluk hidup belajar. Sedangkan belajar adalah berusaha memperoleh kepandaian atau ilmu, berubah tingka laku atau tanggapan yang disebabkan oleh pengalaman (KBBI, 1996: 14).

Sependapat dengan pernyataan tersebut Sutomo (1993: 68) mengemukakan bahwa pembelajaran adalah proses pengelolaan lingkungan seseorang yang dengan sengaja dilakukan sehingga memungkinkan dia belajar untuk melakukan atau mempertunjukkan tingkah laku tertentu pula. Sedangkan belajar adalah suatu peoses yang menyebabkan perubahan tingkah laku yang bukan disebabkan oleh proses pertumbuhan yang bersifat fisik, tetapi perubahan dalam kebiasaan, kecakapan, bertambah, berkembang daya pikir, sikap dan lain-lain. (Soetomo, 1993: 120).

Pasal 1 Undang-undang No. 20 tahun 2003 tentang pendidikan nasional menyebutkan bahwa pembelajaran adalah proses interaksi peserta didik dengan pendidik dan sumber belajar pada suatu lingkungan belajar. Jadi pembelajaran adalah proses yang disengaja yang menyebabkan siswa belajar pada suatu lingkungan belajar untuk melakukan kegiatan pada situasi tertentu. Proses dalam pengertian disini merupakan interaksi semua komponen atau unsur yang terdapat dalam belajar mengajar yang satu sama lainnya saling berhubungan (inter independent) dalam ikatan untuk mencapai tujuan (Usman, 200: 5).

Belajar diartikan sebagai proses perubahan tingka laku pada diri individu berkat adanya interaksi antara individu dengan lingkungannya. Hal ini sesuai dengan yang diutarakan Burton bahwa seseorang setelah mengalami proses belajar akan mengalami perubahan tingkah laku, baik aspek pengetahuannya, keterampilannya, maupun aspek sikapnya. Misalnya dari tidak bisa menjadi bisa, dari tidak mengerti menjadi mengerti. (dalam Usman, 2000: 5).

Mengajar merupakan suatu perbuatan yang memerlukan tanggungjawab moral yang cukup berat. Mengajar pada prinsipnya membimbing siswa dalam kegiatan suatu usaha mengorganisasi lingkungan dalam hubungannya dengan anak didik dan bahan pengajaran yang menimbulkan proses belajar. Proses belajar mengajar merupakan suatu inti dari proses pendidikan secara keseluruhan dengan guru sebagai pemegangn peran utama. Proses belajar mengajar merupakan suatu proses yang mengandung serangkaian perbuatan guru dan siswa atas dasar hubungan timbal balik yang berlangsung dalam situasi edukatif untuk mencapai tujuan tertentu. Interaksi atau hubungan timbal balik antara guru dan siswa itu merupakan syarat utama bagi berlangsungnya proses belajar mengajar (Usman, 2000: 4).

Belajar dapat membawa suatu perubahan pada individu yang belajar. Perubahan ini merupakan pengalaman tingkah laku dari yang kurang baik menjadi lebih baik. Pengalaman dalam belajar merupakan pengalaman yang dituju pada hasil yang akan dicapai siswa dalam proses belajar di sekolah. Pencapaian hasil belajar tersebut dapat diketahui dengan megadakan penilaian tes hasil belajar. Penilaian diadakan 
untuk mengetahui sejauh mana siswa telah berhasil mengikuti pelajaran yang diberikan oleh guru. Di samping itu guru dapat mengetahui sejauh mana keberhasilan guru dalam proses belajar mengajar di sekolah.

Sejalan dengan prestasi belajar, maka dapt diartikan bahwa prestasi belajar Bahasa Inggris adalah nilai yang dipreoleh siswa setelah melibatkan secara langsung/aktif seluruh potensi yang dimilikinya baik aspek kognitif (pengetahuan), afektif (sikap) dan psikomotor (keterampilan) dalam proses belajar mengajar Bahasa Inggris.

Dengan Active Knowledge Sharing Learning proses penerimaan siswa terhadap pelajaran akan lebih berkesan secara mendalam, sehingga membentuk pengertian dengan baik dan sempurna. Juga siswa dapat mengamati dan memperlihatkan pada apa yang diperlihatkan guru selama pelajaran berlangsung.

Adapun penggunan teknik Active Knowledge Sharing Learning mempunyai tujuan agar siswa mampu memahami tentang cara mengatur atau menyusun sesuatu misalnya penggunaan kompor untuk mendidihkan air, cara membuat sesuatu misalnya membuat kertas, dengan Active Knowledge Sharing Learning siswa dapat mengamati bagianbagian dari sesuatu benda ata alat seperti bagian tubuh manusia, atau bagian dari mesin jahit. Juga siswa dapat menyaksikan kerjanya sesuatu alat atau mesin seperti penggunaan gunting dan jalannya mesin jahit. Bila siswa melakukan sendiri demonstasi tersebut, maka ia dapat mengerti juga cara menggunakan sesuatu alat itu seperti menggunakan gunting untuk memotong kain. Dengan demikian siswa akan mengerti cara-cara penggunaan seautu alat atau perkakas, atau suatu mesin, sehingga mereka dapat memilih dan memperbandingkan cara yang terbaik, juga mereka akan mengetahui kebenaran dari sesuatu teori di dalam praktek. Misalnya cara memasak roti yang terbaik.
Bila melaksanakan teknik Active Knowledge Sharing Learning agar berjalan efektif, maka perlu memperhatikan hal-hal sebagai berikut: (1) Guru harus mampu menyusun rumusan tujuan instruksional, agar dapat memberi motivasi yang kuat pada siswa untuk belajar; (2) Pertimbangkanlah baik-baik apakah pilihan teknik anda mampu menjamin tercapainya tujuan yang telah anda rumuskan; (3) Amatilah apakah jumlah siswa memberi kesempatan untuk suatu Active Knowledge Sharing Learning yang berhasil. Bila tidak anda harus mengambil kebijaksaaan lain; (4) Apakah anda telah meneliti alat-alat, atau telah mencoba terlebih dahulu, agar demonstasi itu berhasil; (5) Harus sudah menentukan garis besar langkah-langkah yang akan dilakukan; (6) Apakah tersedia waktu yang cukup, sehingga anda dapat memberi keterangan bila perlu, dan siswa bisa bertanya; (7) Selama Active Knowledge Sharing Learning berlangsung guru harus memberi kesempatan pada siswa untuk mengamati dengan baik dan tertanya; dan (8) Anda perlu mengadakan evaluasi apakah Active Knowledge Sharing Learning yang anda lakukan itu berhasil, dan bila perlu Active Knowledge Sharing Learning bisa diulang.

Motifvasi adalah daya dalam diri seseorang yang mendorongnya untuk melakukan sesuatu, atau keadaan seserang atau organisme yang menyebabkan kesiapan kesiapannya untuk memulai serangkaian tingkah laku atau perbuatan. Sedangkan motivasi adalah suatu proses untuk menggiatkan motif-motif menjadi perbuatan atau tingkah laku untuk memenuhi kebutuhan dan mencapai tujuan, atau keadaan dan kesiapan dalam diri individu yang mendorong tingkah lakunya untuk berbuat sesuatu dalam mencapai tujuan tertentu (Usman, 2000: 28).

Sedangkan menurut Djamarah (2002: 114) motivasi adalah suatu pendorong yang mengubah energi dalam diri seseorang kedalam bentuk aktivitas nyata untuk mencapai tujuan tertentu. 
Dalam proses belajar, motivasi sangat diperlukan sebab seseorang yang tidak mempunyai motivasi dalam belajar tidak akan mungkin melakukan aktivitas belajar. Hal ini sesuai dengan yang diungkapkan oleh Nur (2001: 3) bahwa siswa yang termotivasi dalam belajar sesuatu akan menggunakan proses kognitif yang lebih tinggi dalam mempelajari materi itu, sehingga siswa itu akan meyerap dan mengendapkan mateti itu dengan lebih baik. Jadi motivasi adalah suatu kondisi yang mendorong seseorang untuk berbuat sesuatu dalam mencapai tujuan tertentu.

Penelitian ini menggunakan Penelitian Tindakan Kelas (PTK). Menurut Tim Pelatih Proyek PGSM, PTK adalah suatu bentuk kajian yang bersifat reflektif oleh pelaku tindakan yang dilakukan untuk meningkatkan kemantapan rasional dari tindakan mereka dalam melaksanakan tugas, memperdalam pemahaman terhadap tindakan-tindakan yang dilakukan itu, serta memperbaiki kondisi dimana praktek pembelajaran tersebut dilakukan (dalam Mukhlis, 2000: 3). Sedangkah menurut Mukhlis (2000: 5) PTK adalah suatu bentuk kajian yang bersifat sistematis reflektif oleh pelaku tindakan untuk memperbaiki kondisi pembelajaran yang dilakukan. Adapun tujuan utama dari PTK adalah untuk memperbaiki/meningkatkan pratek pembelajaran secara berkesinambungan, sedangkan tujuan penyertaannya adalah menumbuhkan budaya meneliti di kalangan guru (Mukhlis, 2000: 5).

Sesuai dengan jenis penelitian yang dipilih, yaitu penelitian tindakan, maka penelitian ini menggunakan model penelitian tindakan dari Kemmis dan Taggart (dalam Sugiarti, 1997: 6), yaitu berbentuk spiral dari sklus yang satu ke siklus yang berikutnya. Setiap siklus meliputi planning (rencana), action (tindakan), observation (pengamatan), dan reflection (refleksi). Langkah pada siklus berikutnya adalah perncanaan yang sudah direvisi, tindakan, pengamatan, dan refleksi. Sebelum masuk pada siklus 1 dilakukan tindakan pendahuluan yang berupa identifikasi permasalahan. dari tahap-tahap penelitian tindakan kelas dapat dipaparkan pada sebagai berikut.

1. Rancangan/rencana awal, sebelum mengadakan penelitian peneliti menyusun rumusan masalah, tujuan dan membuat rencana tindakan, termasuk di dalamnya instrumen penelitian dan perangkat pembelajaran.

2. Kegiatan dan pengamatan, meliputi tindakan yang dilakukan oleh peneliti sebagai upaya membangun pemahaman konsep siswa serta mengamati hasil atau dampak dari diterapkannya metode pembelajaran model Active Knowledge Sharing Learning (Pembelajaran yang Mengembangkan Bertbagai Pengetahuan Secara Aktif Pada Siswa).

3. Refleksi, peneliti mengkaji, melihat dan mempertimbangkan hasil atau dampak dari tindakan yang dilakukan berdasarkan lembar pengamatan yang diisi oleh pengamat.

4. Rancangan/rencana yang direvisi, berdasarkan hasil refleksi dari pengamat membuat rancangan yang direvisi untuk dilaksanakan pada siklus berikutnya.

Observasi dibagi dalam tiga putaran, yaitu putaran 1, 2 dan 3, dimana masing putaran dikenai perlakuan yang sama (alur kegiatan yang sama) dan membahas satu sub Kompetensi Dasar Menjelaskan Expression of Admitting and Denying of Doing Something yang diakhiri dengan tes formatif di akhir masing putaran. Dibuat dalam tiga putaran dimaksudkan untuk memperbaiki sistem pengajaran yang telah dilaksanakan.

Instrumen yang digunakan dalam penelitian ini terdiri dari: 
1. Silabus, yaitu seperangkat rencana dan pengaturan tentang kegiatan pembelajaran pengelolahan kelas, serta penilaian hasil belajar.

2. Rencana Pelajaran (RP), yaitu merupakan perangkat pembelajaran yang digunakan sebagai pedoman guru dalam mengajar dan disusun untuk tiap putaran. Masing-masing RP berisi kompetensi dasar, indikator pencapaian hasil belajar, tujuan pembelajaran khusus, dan kegiatan belajar mengajar.

3. Lembar Kegiatan Siswa, adalah lembar kegiatan ini yang dipergunakan siswa untuk membantu proses pengumpulan data hasil eksperimen.

4. Tes formatif, tes ini disusun berdasarkan tujuan pembelajaran yang akan dicapai, digunakan untuk mengukur kemampuan pemahaman konsep Bahasa Inggris pada Kompetensi Dasar Menjelaskan Expression of Admitting and Denying of Doing Something serta penerapannya dalam kehidupan sehari hari melalui Tes formatif ini diberikan setiap akhir putaran. Bentuk soal yang diberikan adalah pilihan guru (objektif). Sebelumnya soal-soal ini berjumlah 46 soal yang telah diujicoba, kemudian penulis mengadakan analisis butir soal tes yang telah diuji validitas dan reliabilitas pada tiap soal. Analisis ini digunakan untuk memilih soal yang baik dan memenuhi syarat digunakan untuk mengambil data. Langkah-langkah analisi butir soal adalah sebagai berikut:

a. Validitas Tes

Validitas butir soal atau validitas item digunakan untuk mengetahui tingkat kevalidan masing-masing butir soal. Sehingga dapat ditentukan butir soal yang gagal dan yang diterima.

b. Reliabilitas

Reliabilitas butir soal dalam penelitian ini menggunakan rumus belah dua sebagai berikut:

$$
\begin{aligned}
& r_{11}=\frac{2 r_{1 / 21 / 2}}{\left(1+r_{1 / 21 / 2}\right)} \quad \text { (Suharsimi } \\
& \text { Arikunto, 20001: 93) } \\
& \text { Dengan: } r_{11} \text { : Koefisien } \\
& \text { reliabilitas yang sudah } \\
& \text { disesuaikan } \\
& r_{1 / 21 / 2} \quad \text { : Korelasi antara } \\
& \text { skor-skor setiap belahan } \\
& \text { tes }
\end{aligned}
$$

Kriteria reliabilitas tes jika harga $r_{11}$ dari perhitungan lebih besar dari harga $r$ pada tabel

c. Taraf Kesukaran

Bilangan yang menunjukkan sukar dan mudahnya suatu soal adalah indeks kesukaran. Rumus yang digunakan untuk menentukan taraf kesukaran adalah:

$P=\frac{B}{J S} \quad$ (Suharsimi Arikunto,

Dengan:

$\mathrm{P} \quad$ : Indeks kesukaran

B : Banyak siswa yang menjawab soal dengan benar

Js : Jumlah seluruh siswa peserta tes

Kriteria untuk menentukan indeks kesukaran soal adalah sebagai berikut:

- Soal dengan $P=0,000$ sampai 0,300 adalah sukar

- Soal dengan $P=0,301$ sampai 0,700 adalah sedang

- Soal dengan $P=0,701$ sampai 1,000 adalah mudah

d. Daya Pembeda

Daya pembeda soal adalah kemampuan suatu soal untuk membedakan antara siswa yang berkemampuan tinggi dengan siswa yang berkemampuan rendah. Angka yang menunjukkan besarnya daya pembeda desebut indeks diskriminasi. Rumus yang digunakan untuk menghitung indeks diskriminasi adalah sebagai berikut:

$$
\begin{gathered}
D=\frac{B_{A}}{J_{A}}-\frac{B_{B}}{J_{B}}=P_{A}-P_{B} \\
\text { (Suharsimi Arikunto, } \\
\text { 2001: 211) }
\end{gathered}
$$




\section{Dimana:}

$$
\begin{array}{cl}
\mathrm{D} & \text { : Indeks diskriminasi } \\
\mathrm{B}_{\mathrm{A}} & \begin{array}{l}
\text { : Banyak peserta kelompok } \\
\text { atas yang menjawab dengan } \\
\text { benar }
\end{array} \\
& \begin{array}{l}
\text { : Banyak peserta kelompok } \\
\text { bawah yang menjawab } \\
\text { dengan benar }
\end{array} \\
& \begin{array}{l}
\text { : Jumlah peserta kelompok } \\
\text { atas }
\end{array} \\
\mathrm{J}_{\mathrm{A}} \quad \text { Jumlah peserta kelompok } \\
\mathrm{J}_{\mathrm{B}} \quad \begin{array}{l}
\text { bawah } \\
P_{A}=\frac{B_{A}}{J_{A}}=
\end{array} \\
\quad \text { Proporsi peserta kelompok } \\
P_{B}=\frac{B_{B}}{J_{B}}=
\end{array}
$$
bawah yang menjawab benar Kriteria yang digunakan untuk menentukan daya pembeda butir soal sebagai berikut:

- Soal dengan $D=0,000$ sampai 0,200 adalah jelek

- Soal dengan $D=0,201$ sampai 0,320 adalah cukup

- Soal dengan $\mathrm{D}=0,321$ sampai 0,700 adalah baik

- Soal dengan $D=0,701$ sampai 1,000 adalah sangat baik

Melalui pemaparan Data-data yang diperlukan dalam penelitian ini diperoleh melalui observasi pengolahan belajar dengan metode Active Knowledge Sharing Learning (Pembelajaran yang Mengembangkan Bertbagai Pengetahuan Secara Aktif Pada Siswa), observasi aktivitas siswa dan guru, dan tes formatif.

Untuk mengetahui keefektivan suatu metode dalam kegiatan pembelajaran perlu diadakan analisa data. Pada penelitian ini menggunakan teknik analisis deskriptif kualitatif, yaitu suatu metode penelitian yang bersifat menggambarkan kenyataan atau fakta sesuai dengan data yang diperoleh dengan tujuan untuk mengetahui prestasi belajar yang dicapai siswa juga untuk HASIL DAN PEMBAHASAN

\section{Siklus I}

memperoleh respon siswa terhadap kegiatan pembelajaran serta aktivitas siswa selama proses pembelajaran.

Untuk mengalisis tingkat keberhasilan atau persentase keberhasilan siswa setelah proses belajar mengajar setiap putarannya dilakukan dengan cara memberikan evaluasi berupa soal tes tertulis pada setiap akhir putaran.

Analisis ini dihitung dengan menggunakan statistic sederhana yaitu:

1. Untuk menilai ulangan atau tes formatif

Peneliti melakukan penjumlahan nilai yang diperoleh siswa, yang selanjutnya dibagi dengan jumlah siswa yang ada di kelas tersebut sehingga diperoleh rata-rata tes formatif dapat dirumuskan:

$$
\bar{X}=\frac{\sum X}{\sum N}
$$

Dengan : $\bar{X} \quad=$ Nilai rata-rata

$\Sigma \mathrm{X}=$ Jumlah semua nilai siswa

$\Sigma \mathrm{N}=$ Jumlah siswa

2. Untuk ketuntasan belajar Ada dua kategori ketuntasan belajar yaitu secara perorangan dan secara klasikal. Berdasarkan petunjuk pelaksanaan belajar mengajar kurikulum 1994 (Depdikbud, 1994), yaitu seorang siswa telah tuntas belajar bila telah mencapai skor $65 \%$ atau nilai 65, dan kelas disebut tuntas belajar bila di kelas tersebut terdapat $85 \%$ yang telah mencapai daya serap lebih dari atau sama dengan 65\%. Untuk menghitung persentase ketuntasan belajar digunakan rumus sebagai berikut:

$$
P=\frac{\sum \text { Siswa.yang.tuntas.belajar }}{\sum \text { Siswa }} \times 100 \%
$$


Tabel 1. Distribusi Nilai Tes Pada Siklus I

\begin{tabular}{|c|c|c|c|c|}
\hline \multirow{2}{*}{ No } & \multirow{2}{*}{ Nama } & \multirow{2}{*}{ Skoor } & \multicolumn{2}{|c|}{ Aktivitas } \\
\hline & & & $\mathrm{T}$ & TT \\
\hline 1 & ANGGER SUBEKTI & 70 & $\mathrm{~V}$ & \\
\hline 2 & ANIS NUR ROFIKAH & 74 & V & \\
\hline 3 & ARUM SARASWATI & 70 & & $\mathrm{~V}$ \\
\hline 4 & BAMBANG WIDODO & 74 & $\mathrm{~V}$ & \\
\hline 5 & BUDI SANTOSO & 60 & & $\mathrm{~V}$ \\
\hline 6 & DEVID NOVIANTO & 74 & $\mathrm{~V}$ & \\
\hline 7 & DEWI SULAMSIH & 60 & & $\mathrm{~V}$ \\
\hline 8 & DIAN SETIATI & 66 & & $\mathrm{~V}$ \\
\hline 9 & DYAH AYU PUTRI L & 70 & $\mathrm{~V}$ & \\
\hline 10 & ENDAH PUJI RAHAYU & 74 & $\mathrm{~V}$ & \\
\hline 11 & ENDAH SUCI RA & 60 & & $\mathrm{~V}$ \\
\hline 12 & ENDAH SULISTYOWATI & 65 & & $\mathrm{~V}$ \\
\hline 13 & ERWI PUJI ASTUTIK & 70 & $\mathrm{~V}$ & \\
\hline 14 & FIANA SHOLICHAH & 74 & $\mathrm{~V}$ & \\
\hline 15 & GUNUNG SURYO W & 70 & $\mathrm{~V}$ & \\
\hline 16 & HARIYANTO & 74 & $\mathrm{~V}$ & \\
\hline 17 & HENGKY SETIAWAN & 70 & $\mathrm{~V}$ & \\
\hline 18 & HERU PRASETYO & 60 & & $\mathrm{~V}$ \\
\hline 19 & IRFAN MARZUKI & 70 & $\mathrm{~V}$ & \\
\hline 20 & ISBIATUN & 70 & $\mathrm{~V}$ & \\
\hline 21 & JOKO NURGIANTO & 74 & $\mathrm{~V}$ & \\
\hline 22 & JUMIA IKA ARWATIK & 70 & & $\mathrm{~V}$ \\
\hline 23 & KHOIRON ARIFUL M & 70 & $\mathrm{~V}$ & \\
\hline 24 & KHOIRUL IHSAN & 70 & $\mathrm{~V}$ & \\
\hline 25 & MADE HERMAWAN & 72 & $\mathrm{~V}$ & \\
\hline 26 & NIKMATUS SARIFAH & 70 & & $\mathrm{~V}$ \\
\hline 27 & RAGIL TRIHERMAWATI & 70 & $\mathrm{~V}$ & \\
\hline 28 & RIDWAN & 74 & $\mathrm{~V}$ & \\
\hline 29 & RIKA SANDRA DWI 0 & 70 & $\mathrm{~V}$ & \\
\hline 30 & RINITA ANDRIYANI & 70 & $\mathrm{~V}$ & \\
\hline 31 & RIYAN TRI AHMADI & 74 & $\mathrm{~V}$ & \\
\hline \multirow[t]{4}{*}{32} & YUDI SUSILO & 70 & & $\mathrm{~V}$ \\
\hline & & 2229 & & \\
\hline & & 69,66 & & \\
\hline & & $69,66 \%$ & & \\
\hline
\end{tabular}

Dari tabel di atas dapat dijelaskan bahwa dengan menerapkan metode Active Knowledge Sharing Learning diperoleh nilai rata-rata prestasi belajar siswa adalah 69,66 dan ketuntasan belajar mencapai $69,66 \%$ atau ada 28 siswa dari 32 siswa sudah tuntas belajar. Hasil tersebut menunjukkan bahwa pada siklus pertama secara klasikal siswa belum tuntas belajar, karena siswa yang memperoleh nilai $\geq 65$ hanya sebesar $69,66 \%$ lebih kecil dari persentase ketuntasan yang dikehendaki yaitu sebesar $85 \%$. Hal ini disebabkan karena siswa masih merasa baru dan belum mengerti apa yang dimaksudkan dan digunakan guru dengan menerapkan metode Active Knowledge Sharing Learning. Pada materi pembelajaran dalam Menjelaskan Expression of Admitting and Denying of Doing Something serta penerapannya dalam kehidupan sehari hari. 


\section{Siklus II}

Tabel 2. Distribusi Nilai Tes Pada Siklus II

\begin{tabular}{|c|c|c|c|c|}
\hline \multirow{2}{*}{ No } & \multirow{2}{*}{ Nama } & \multirow{2}{*}{ Skoor } & \multicolumn{2}{|c|}{ Aktivitas } \\
\hline & & & $\mathrm{T}$ & TT \\
\hline 1 & ANGGER SUBEKTI & 75 & $\mathrm{~V}$ & \\
\hline 2 & ANIS NUR ROFIKAH & 80 & V & \\
\hline 3 & ARUM SARASWATI & 80 & V & \\
\hline 4 & BAMBANG WIDODO & 80 & $\mathrm{~V}$ & \\
\hline 5 & BUDI SANTOSO & 75 & & $\mathrm{~V}$ \\
\hline 6 & DEVID NOVIANTO & 80 & $\mathrm{~V}$ & \\
\hline 7 & DEWI SULAMSIH & 75 & & $\mathrm{~V}$ \\
\hline 8 & DIAN SETIATI & 70 & $\mathrm{~V}$ & \\
\hline 9 & DYAH AYU PUTRI L & 70 & $\mathrm{~V}$ & \\
\hline 10 & ENDAH PUJI RAHAYU & 80 & V & \\
\hline 11 & ENDAH SUCI RA & 75 & & $\mathrm{~V}$ \\
\hline 12 & ENDAH SULISTYOWATI & 75 & & $\mathrm{~V}$ \\
\hline 13 & ERWI PUJI ASTUTIK & 70 & V & \\
\hline 14 & FIANA SHOLICHAH & 80 & $\mathrm{~V}$ & \\
\hline 15 & GUNUNG SURYO W & 70 & $\mathrm{~V}$ & \\
\hline 16 & HARIYANTO & 80 & $\mathrm{~V}$ & \\
\hline 17 & HENGKY SETIAWAN & 70 & $\mathrm{~V}$ & \\
\hline 18 & HERU PRASETYO & 75 & & $\mathrm{~V}$ \\
\hline 19 & IRFAN MARZUKI & 70 & $\mathrm{~V}$ & \\
\hline 20 & ISBIATUN & 70 & $\mathrm{~V}$ & \\
\hline 21 & JOKO NURGIANTO & 80 & $\mathrm{~V}$ & \\
\hline 22 & JUMIA IKA ARWATIK & 75 & & $\mathrm{~V}$ \\
\hline 23 & KHOIRON ARIFUL M & 75 & & $\mathrm{~V}$ \\
\hline 24 & KHOIRUL IHSAN & 70 & $\mathrm{~V}$ & \\
\hline 25 & MADE HERMAWAN & 70 & $\mathrm{~V}$ & \\
\hline 26 & NIKMATUS SARIFAH & 70 & $\mathrm{~V}$ & \\
\hline 27 & RAGIL TRIHERMAWATI & 75 & & $\mathrm{~V}$ \\
\hline 28 & RIDWAN & 80 & $\mathrm{~V}$ & \\
\hline 29 & RIKA SANDRA DWI 0 & 70 & $\mathrm{~V}$ & \\
\hline 30 & RINITA ANDRIYANI & 70 & $\mathrm{~V}$ & \\
\hline 31 & RIYAN TRI AHMADI & 80 & $\mathrm{~V}$ & \\
\hline 32 & YUDI SUSILO & 70 & V & \\
\hline & & 2385 & & \\
\hline & & 74,53 & & \\
\hline & & $74,53 \%$ & & \\
\hline
\end{tabular}

Dari tabel di atas diperoleh nilai rata-rata prestasi belajar siswa adalah 74,53 dan ketuntasan belajar mencapai $74,53 \%$ atau ada 32 siswa dari 32 siswa sudah tuntas belajar. Hasil ini menunjukkan bahwa pada siklus II ini ketuntasan belajar secara klasikal telah mengalami peningkatan sedikit lebih baik dari siklus I. Adanya peningkatan hasil belajar siswa ini karena setelah guru menginformasikan bahwa setiap akhir pelajaran akan selalu diadakan tes sehingga pada pertemuan berikutnya siswa lebih termotivasi untuk belajar. Selain itu siswa juga sudah mulai mengerti apa yang dimaksudkan dan dinginkan guru dengan menerapkan metode Active Knowledge Sharing Learning. Pada materi pembelajaran dalam Menjelaskan Expression of Admitting and Denying of Doing Something serta penerapannya dalam kehidupan sehari hari. 


\section{Siklus III}

Tabel 3. Distribusi Nilai Tes Pada Siklus III

\begin{tabular}{|c|c|c|c|c|}
\hline \multirow{2}{*}{ No } & \multirow{2}{*}{ Nama } & \multirow{2}{*}{ Skoor } & \multicolumn{2}{|c|}{ Aktivitas } \\
\hline & & & $\mathrm{T}$ & TT \\
\hline 1 & ANGGER SUBEKTI & 85 & $\mathrm{~V}$ & \\
\hline 2 & ANIS NUR ROFIKAH & 80 & V & \\
\hline 3 & ARUM SARASWATI & 80 & V & \\
\hline 4 & BAMBANG WIDODO & 80 & $\mathrm{~V}$ & \\
\hline 5 & BUDI SANTOSO & 85 & $\mathrm{~V}$ & \\
\hline 6 & DEVID NOVIANTO & 80 & $\mathrm{~V}$ & \\
\hline 7 & DEWI SULAMSIH & 85 & & $\mathrm{~V}$ \\
\hline 8 & DIAN SETIATI & 85 & V & \\
\hline 9 & DYAH AYU PUTRI L & 85 & $\mathrm{~V}$ & \\
\hline 10 & ENDAH PUJI RAHAYU & 80 & V & \\
\hline 11 & ENDAH SUCI RA & 85 & V & \\
\hline 12 & ENDAH SULISTYOWATI & 80 & V & \\
\hline 13 & ERWI PUJI ASTUTIK & 85 & $\mathrm{~V}$ & \\
\hline 14 & FIANA SHOLICHAH & 85 & $\mathrm{~V}$ & \\
\hline 15 & GUNUNG SURYO W & 85 & $\mathrm{~V}$ & \\
\hline 16 & HARIYANTO & 80 & $\mathrm{~V}$ & \\
\hline 17 & HENGKY SETIAWAN & 85 & $\mathrm{~V}$ & \\
\hline 18 & HERU PRASETYO & 80 & & $\mathrm{~V}$ \\
\hline 19 & IRFAN MARZUKI & 85 & V & \\
\hline 20 & ISBIATUN & 85 & V & \\
\hline 21 & JOKO NURGIANTO & 85 & V & \\
\hline 22 & JUMIA IKA ARWATIK & 80 & V & \\
\hline 23 & KHOIRON ARIFUL M & 85 & V & \\
\hline 24 & KHOIRUL IHSAN & 80 & $\mathrm{~V}$ & \\
\hline 25 & MADE HERMAWAN & 85 & $\mathrm{~V}$ & \\
\hline 26 & NIKMATUS SARIFAH & 85 & $\mathrm{~V}$ & \\
\hline 27 & RAGIL TRIHERMAWATI & 85 & & \\
\hline 28 & RIDWAN & 80 & $\mathrm{~V}$ & \\
\hline 29 & RIKA SANDRA DWI 0 & 80 & $\mathrm{~V}$ & \\
\hline 30 & RINITA ANDRIYANI & 85 & $\mathrm{~V}$ & \\
\hline 31 & RIYAN TRI AHMADI & 85 & $\mathrm{~V}$ & \\
\hline 32 & YUDI SUSILO & 84 & V & \\
\hline & & 2659 & & \\
\hline & & 83,09 & & \\
\hline & & $83,09 \%$ & & \\
\hline
\end{tabular}

Berdasarkan tabel diatas diperoleh nilai rata-rata tes formatif sebesar 83,09 dan dari 32 siswa yang telah tuntas sebanyak 32 siswa dan 3 siswa belum mencapai ketuntasan belajar. Maka secara klasikal ketuntasan belajar yang telah tercapai sebesar 83,09\% (termasuk kategori tuntas). Hasil pada siklus III ini mengalami peningkatan lebih baik dari siklus II. Adanya peningkatan hasil belajar pada siklus III ini dipengaruhi oleh adanya peningkatan kemampuan guru dalam menerapkan belajar dengan metode Active Knowledge Sharing
Learning sehingga siswa menjadi lebih terbiasa dengan pembelajaran seperti ini sehingga siswa lebih mudah dalam memahami materi yang telah diberikan. Pada materi pembelajaran dalam Menjelaskan Expression of Admitting and Denying of Doing Something serta penerapannya dalam kehidupan sehari hari.
c. Refleksi
Pada tahap ini akah dikaji apa yang telah terlaksana dengan baik maupun yang masih kurang baik dalam proses belajar mengajar 
dengan Peranan Metode Active Knowledge Sharing Learning. Dari data-data yang telah diperoleh dapat diuraikan sebagai berikut:

1) Selama proses belajar mengajar guru telah melaksanakan semua pembelajaran dengan baik. Meskipun ada beberapa aspek yang belum sempurna, tetapi persentase pelaksanaannya untuk masingmasing aspek cukup besar.

2) Berdasarkan data hasil pengamatan diketahui bahwa siswa aktif selama proses belajar berlangsung. Pada materi pembelajaran dalam Menjelaskan Expression of Admitting and Denying of Doing Something serta penerapannya dalam kehidupan sehari hari.

3) Kekurangan pada siklus-siklus sebelumnya sudah mengalami perbaikan dan peningkatan sehingga menjadi lebih baik.

4) Hasil belajar siswsa pada siklus III mencapai ketuntasan.

d. Revisi Pelaksanaan

Pada siklus III guru telah menerapkan belajar dengan metode Active Knowledge Sharing Learning dengan baik dan dilihat dari aktivitas siswa serta hasil belajar siswa pelaksanaan proses belajar mengajar sudah berjalan dengan baik. Maka tidak diperlukan revisi terlalu banyak, tetapi yang perlu diperhatikan untuk tindakah selanjutnya adalah memaksimalkan dan mempertahankan apa yang telah ada dengan tujuan agar pada pelaksanaan proses belajar mengajar selanjutnya Peranan Metode Active Knowledge Sharing Learning dapat meningkatkan dalam proses belajar mengajar Pada materi pembelajaran dalam Menjelaskan Expression of Admitting and Denying of Doing Something serta penerapannya dalam kehidupan sehari hari. sehingga tujuan pembelajaran dapat tercapai. Hal ini dapat dilihat melalui perbandingan antar siklus seperti yang tertera dibawah ini : 
Tabel 4. Perbandingan Hasil Perolehan Skor pada setiap Siklus

\begin{tabular}{|c|c|c|c|c|}
\hline \multirow{2}{*}{ No } & \multirow{2}{*}{ Nama Siswa } & \multicolumn{3}{|c|}{ Hasil Skoor Pada Siklus } \\
\hline & & Siklus I & Siklus II & Siklus II \\
\hline 1 & ANGGER SUBEKTI & 70 & 75 & 85 \\
\hline 2 & ANIS NUR ROFIKAH & 74 & 80 & 80 \\
\hline 3 & ARUM SARASWATI & 70 & 80 & 80 \\
\hline 4 & BAMBANG WIDODO & 74 & 80 & 80 \\
\hline 5 & BUDI SANTOSO & 60 & 75 & 85 \\
\hline 6 & DEVID NOVIANTO & 74 & 80 & 80 \\
\hline 7 & DEWI SULAMSIH & 60 & 75 & 85 \\
\hline 8 & DIAN SETIATI & 66 & 70 & 85 \\
\hline 9 & DYAH AYU PUTRI L & 70 & 70 & 85 \\
\hline 10 & ENDAH PUJI RAHAYU & 74 & 80 & 80 \\
\hline 11 & ENDAH SUCI RA & 60 & 75 & 85 \\
\hline 12 & ENDAH SULISTYOWATI & 65 & 75 & 80 \\
\hline 13 & ERWI PUJI ASTUTIK & 70 & 70 & 85 \\
\hline 14 & FIANA SHOLICHAH & 74 & 80 & 85 \\
\hline 15 & GUNUNG SURYO W & 70 & 70 & 85 \\
\hline 16 & HARIYANTO & 74 & 80 & 80 \\
\hline 17 & HENGKY SETIAWAN & 70 & 70 & 85 \\
\hline 18 & HERU PRASETYO & 60 & 75 & 80 \\
\hline 19 & IRFAN MARZUKI & 70 & 70 & 85 \\
\hline 20 & ISBIATUN & 70 & 70 & 85 \\
\hline 21 & JOKO NURGIANTO & 74 & 80 & 85 \\
\hline 22 & JUMIA IKA ARWATIK & 70 & 75 & 80 \\
\hline 23 & KHOIRON ARIFUL M & 70 & 75 & 85 \\
\hline 24 & KHOIRUL IHSAN & 70 & 70 & 80 \\
\hline 25 & MADE HERMAWAN & 72 & 70 & 85 \\
\hline 26 & NIKMATUS SARIFAH & 70 & 70 & 85 \\
\hline 27 & RAGIL TRIHERMAWATI & 70 & 75 & 85 \\
\hline 28 & RIDWAN & 74 & 80 & 80 \\
\hline 29 & RIKA SANDRA DWI 0 & 70 & 70 & 80 \\
\hline 30 & RINITA ANDRIYANI & 70 & 70 & 85 \\
\hline 31 & RIYAN TRI AHMADI & 74 & 80 & 85 \\
\hline \multirow[t]{4}{*}{32} & YUDI SUSILO & 70 & 70 & 84 \\
\hline & Jumlah & 2229 & 2385 & 2659 \\
\hline & Rata rata Nilai & 69,66 & 74,53 & 83,09 \\
\hline & Prosentase & $69,66 \%$ & $74,53 \%$ & $83,09 \%$ \\
\hline
\end{tabular}

Melalui hasil peneilitian ini menunjukkan bahwa metode Active Knowledge Sharing Learning memiliki dampak positif dalam meningkatkan prestasi belajar siswa. Hal ini dapat dilihat dari semakin mantapnya pemahaman siswa terhadap materi yang disampaikan guru (ketuntasan belajar meningkat dari sklus I, II, dan III) yaitu masing-masing 69,66\%, 74,53\%, dan 83,09\%. Pada siklus III ketuntasan belajar siswa secara klasikal telah tercapai.

Berdasarkan analisis data, diperoleh aktivitas siswa dalam proses pembelajaran dalam setiap siklus mengalami peningkatan. Hal ini berdampak positif terhadap prestasi belajar siswa yaitu dapat ditunjukkan dengan meningkatnya nilai rata-rata siswa pada setiap siklus yang terus mengalami peningkatan. Pada materi pembelajaran dalam Menjelaskan Expression of Admitting and Denying of Doing Something serta penerapannya dalam kehidupan sehari hari.

Pada Siklus I diperoleh nilai ratarata prestasi belajar siswa adalah 69,66 dan ketuntasan belajar mencapai 69,66\% atau ada 28 siswa dari 32 siswa sudah tuntas belajar. Hasil tersebut menunjukkan bahwa pada siklus pertama secara klasikal siswa belum tuntas 
belajar, karena siswa yang memperoleh nilai $\geq 65$ hanya sebesar 69,66\% lebih kecil dari persentase ketuntasan yang dikehendaki yaitu sebesar $85 \%$. Hal ini disebabkan karena siswa masih merasa baru dan belum mengerti apa yang dimaksudkan dan digunakan guru dengan menerapkan metode Active Knowledge Sharing Learning.

Pada Siklus II diperoleh nilai ratarata prestasi belajar siswa adalah 74,53 dan ketuntasan belajar mencapai 74,53\% atau ada 32 siswa dari 32 siswa sudah tuntas belajar. Hasil ini menunjukkan bahwa pada siklus II ini ketuntasan belajar secara klasikal telah mengalami peningkatan sedikit lebih baik dari siklus I. Adanya peningkatan hasil belajar siswa ini karena setelah guru menginformasikan bahwa setiap akhir pelajaran akan selalu diadakan tes sehingga pada pertemuan berikutnya siswa lebih termotivasi untuk belajar.

Pada Siklus III diperoleh nilai rata-rata tes formatif sebesar 83,09 dan dari 32 siswa yang telah tuntas sebanyak 32 siswa dan 3 siswa belum mencapai ketuntasan belajar. Maka secara klasikal ketuntasan belajar yang telah tercapai sebesar 83,09\% (termasuk kategori tuntas). Hasil pada siklus III ini mengalami peningkatan lebih baik dari siklus II. Adanya peningkatan hasil belajar pada siklus III ini dipengaruhi oleh

\section{SIMPULAN DAN SARAN Simpulan}

Dari hasil kegiatan pembelajaran yang telah dilakukan selama tiga siklus, dan berdasarkan seluruh pembahasan serta analisis yang telah dilakukan dapat disimpulkan sebagai berikut. (1) Pembelajaran dengan metode Active Knowledge Sharing Learning memiliki dampak positif dalam meningkatkan prestasi belajar siswa yang ditandai dengan peningkatan ketuntasan belajar siswa dalam setiap siklus, yaitu siklus I (69,66\%), siklus II $(74,53 \%)$, siklus III (83,09\%); (2) Peranan Metode Active Knowledge Sharing Learning mempunyai pengaruh positif, yaitu dapat adanya peningkatan kemampuan guru dalam menerapkan belajar dengan metode Active Knowledge Sharing Learning. Berdasarkan analisis data, diperoleh aktivitas siswa dalam proses pembelajaran Bahasa Inggris pada Kompetensi Dasar Menjelaskan Expression of Admitting and Denying of Doing Something serta penerapannya dalam kehidupan sehari hari dengan metode Active Knowledge Sharing Learning yang paling dominan adalah mendengarkan/ memperhatikan penjelasan guru, dan diskusi antar siswa/antara siswa dengan guru. Jadi dapat dikatakan bahwa aktivitas siswa dapat dikategorikan aktif. Pada materi pembelajaran dalam Menjelaskan Expression of Admitting and Denying of Doing Something serta penerapannya dalam kehidupan sehari hari.

Sedangkan untuk aktivitas guru selama pembelajaran telah melaksanakan langkah-langkah belajar dengan metode Active Knowledge Sharing Learning dengan baik. Hal ini terlihat dari aktivitas guru yang muncul di antaranya aktivitas membimbing dan mengamati siswa dalam mengerjakan kegiatan LKS/menemukan konsep, menjelaskan, memberi umpan balik/evaluasi/tanya jawab dimana prosentase untuk aktivitas di atas cukup besar.

meningkatkan motivasi belajar siswa Pada materi pembelajaran dalam Menjelaskan Expression of Admitting and Denying of Doing Something serta penerapannya dalam kehidupan sehari hari. yang ditunjukan dengan rata-rata jawaban siswa hasil wawancara yang menyatakan bahwa siswa tertarik dan berminat dengn metode Active Knowledge Sharing Learning sehingga mereka menjadi termotivasi untuk belajar; (3) Pada Siklus I diperoleh nilai rata-rata prestasi belajar siswa adalah 69,66 dan ketuntasan belajar mencapai $69,66 \%$ atau ada 28 siswa dari 32 siswa sudah tuntas belajar. Hasil tersebut menunjukkan bahwa pada siklus pertama 
secara klasikal siswa belum tuntas belajar, karena siswa yang memperoleh nilai $\geq 65$ hanya sebesar $69,66 \%$ lebih kecil dari persentase ketuntasan yang dikehendaki yaitu sebesar $85 \%$. Hal ini disebabkan karena siswa masih merasa baru dan belum mengerti apa yang dimaksudkan dan digunakan guru dengan menerapkan metode Active Knowledge Sharing Learning (Pembelajaran yang Mengembangkan Bertbagai Pengetahuan Secara Aktif Pada Siswa); (4) Pada Siklus II diperoleh nilai rata-rata prestasi belajar siswa adalah 74,53 dan ketuntasan belajar mencapai $74,53 \%$ atau ada 32 siswa dari 32 siswa sudah tuntas belajar. Hasil ini menunjukkan bahwa pada siklus II ini ketuntasan belajar secara klasikal telah mengalami peningkatan sedikit lebih baik dari siklus I. Adanya peningkatan hasil belajar siswa ini karena setelah guru menginformasikan bahwa setiap akhir pelajaran akan selalu diadakan tes sehingga pada pertemuan berikutnya siswa lebih termotivasi untuk belajar; dan (5) Pada Siklus III diperoleh nilai ratarata tes formatif sebesar 83,09 dan dari 32 siswa yang telah tuntas sebanyak 32 siswa dan 3 siswa belum mencapai ketuntasan belajar. Maka secara klasikal ketuntasan belajar yang telah tercapai sebesar 83,09\% (termasuk kategori tuntas). Hasil pada siklus III ini mengalami peningkatan lebih baik dari siklus II. Adanya peningkatan hasil belajar pada siklus III ini dipengaruhi oleh adanya peningkatan kemampuan guru dalam menerapkan belajar dengan

\section{DAFTAR PUSTAKA}

Ali, Muhammad. (1996). Guru Dalam Proses Belajar Mengajar. Bandung: Sinar Baru Algesindon.

Arikunto, Suharsimi. (1993). Manajemen Mengajar Secara Manusiawi. Jakarta: Rineksa Cipta.

Arikunto, Suharsimi. (1998). Prosedur Penelitian Suatu Pendekatan Praktek. Jakarta: Rineksa Cipta metode Active Knowledge Sharing Learning.

\section{Saran}

Dari hasil penelitian yang diperoleh dari uraian sebelumnya agar proses belajar mengajar Bahasa Inggris lebih efektif dan lebih memberikan hasil yang optimal bagi siswa, makan disampaikan saran sebagai berikut. (1) Untuk melaksanakan belajar dengan metode Active Knowledge Sharing Learning memerlukan persiapan yang cukup matang, sehingga guru harus mempu menentukan atau memilih topik Pada materi pembelajaran dalam Menjelaskan Expression of Admitting and Denying of Doing Something serta penerapannya dalam kehidupan sehari hari. yang benar-benar bisa diterapkan dengan metode Active Knowledge Sharing Learning dalam proses belajar mengajar sehingga diperoleh hasil yang optimal; (2) Dalam rangka meningkatkan prestasi belajar siswa, guru hendaknya lebih sering melatih siswa dengan berbagai metode, walau dalam taraf yang sederhana, dimana siswa nantinya dapat menemukan pengetahuan baru, memperoleh konsep dan keterampilan, sehingga siswa berhasil atau mampu memecahkan masalah-masalah yang dihadapinya; (3) Perlu adanya penelitian yang lebih lanjut, karena hasil penelitian ini hanya dilakukan di Siswa Kelas XIIIPA-1 Semester Ganjil di SMA Negeri 2 Madiun, Kota Madiun pada Tahun Pelajaran 2019/2020; dan (4) Untuk penelitian yang serupa hendaknya dilakukan perbaikan-perbaikan agar diperoleh hasil yang lebih baik.

Combs. Arthur. W. (1984). The Profesional Education of Teachers. Allin and Bacon, Inc. Boston.

Dahar, R.W. (1989). Teori-teori Belajar. Jakarta: Erlangga.

Departemen Pendidikan dan Kebudayaan. (1994). Petunjuk Pelaksanaan Proses Belajar Mengajar, Jakarta. Balai Pustaka.

Djamarah, Syaiful Bahri. (2000). Strategi Belajar Mengajar. Jakarta: Rineksa Cipta. 
Hamalik, Oemar. (1994). Metode Pendidikan. Bandung: Citra Aditya Bakti.

Hasibuan. J.J. dan Moerdjiono. (1998). Proses Belajar Mengajar. Bandung: Remaja Rosdakarya.

Hudoyo, H. (1990). Strategi Belajar Mengajar Bahasa Inggris. Malang: IKIP Malang.

Kemmis, S. dan Mc. Taggart, R. (1988). The Action Research Planner. Victoria Dearcin University Press.

Margono. (1997). Metodologi Penelitian Pendidikan. Jakarta. Rineksa Cipta.

Ngalim, Purwanto M. (1990). Psikologi Pendidikan. Bandung: PT. Remaja Rosdakarya.

Purwanto, N. (1988). Prinsip-prinsip dan Teknis Evaluasi Pengajaran. Bandung. Remaja Rosda Karya.

Rustiyah, N.K. (1991). Strategi Belajar Mengajar. Jakarta: Bina Aksara.

Saliwangi, B. (1988). Pengantar Strategi Belajar Mengajar Bahasa Indonesia. Malang: IKIP Malang.

Sardiman, A.M. (1996). Interaksi dan Motivasi Belajar Mengajar. Jakarta: Bina Aksara.

Soekamto, Toeti. (1997). Teori Belajar dan Model Pembelajaran. Jakarta: PAU-PPAI, Universitas Terbuka.

Syah, Muhibbin. (1995). Psikologi Pendidikan, Suatu Pendekatan Baru. Bandung: Remaja Rosdakarya.

Usman, Moh. Uzer. (2001). Menjadi Guru Profesional. Bandung: Remaja Rosdakarya.

Wetherington. H.C. and W.H. Walt. Burton. (1986). Teknik-teknik Belajar dan Mengajar. (terjemahan) Bandung: Jemmars. 